\title{
Contextualizing Leadership Upon Followers' Unique Characteristics: An Argument for Explicit Consideration of Accurate Person Perception
}

\author{
Douglas E. Colman \\ Idaho State University \\ A New Hope, LLC \\ Robert W. Lion \\ Idaho State University
}

\begin{abstract}
Leadership scholarship, in terms of theories and models, continues to make risky assumptions that the person in a leader role accurately accounts for not only follower behavior, but also the motives and personality aspects from which said behaviors manifest. In this paper we propose an integrated path model that utilizes both Leader-Member Exchange and Transformational Leadership, while explicitly focusing on the science behind interpersonal judgment accuracy. It is only by having an accurate understanding of the follower, which has been a long held untested assumption, can congruence be purposely obtained, narrowing the gap between ideology and practice.
\end{abstract}

Keywords: transformational leadership, leader-member exchange, person perception accuracy, individual differences, organizational behavior

\section{INTRODUCTION}

One is hard pressed to think about business without consideration of dealings between organizations and the entities (persons or other firms alike) to which they provide goods and/or services. Just as important, but often a much less salient consideration, is the relationship between an organization and its workforce. Most often this bi-directional relationship is perceived as an exchange process (e.g., employee provides labor for which the organization provides monetary compensation). However, there is more to the employee-organization link than a simple economic interchange. Individuals look to their organization as contributing to their social status and identity (Jahoda, 1981), a source of social support (Baruch-Feldman, Brondolo, Ben-Dayan, \& Schwartz, 2002), and a place to expand their knowledge and skills (Dansereau, Seitz, Chiu, Shaughnessy, \& Yammarino, 2013; McIntyre, Mattingly, Lewandowski, \& Simpson, 2014). Employee behaviors and attitudes are driven by their sense of connection with the organization; therefore, an inquiry as to how one might improve such employee views is warranted. While myriad influences could be discussed at length, a select few are discussed within this paper. Specifically, we propose an integrated path model that focuses on the relationships between motivation, personality traits, and self-concept and how such constructs mediate leader-member exchange and transformational leadership. We take this view further by also exploring the role accuracy of judgment of follower attributes plays in the model (see Figure $1)$. 


\section{FIGURE 1 \\ CONCEPTUAL FRAMEWORK OF THE CONSTRUCTS INCLUDED IN THE PROPOSED INTEGRATIVE PATH MODEL}

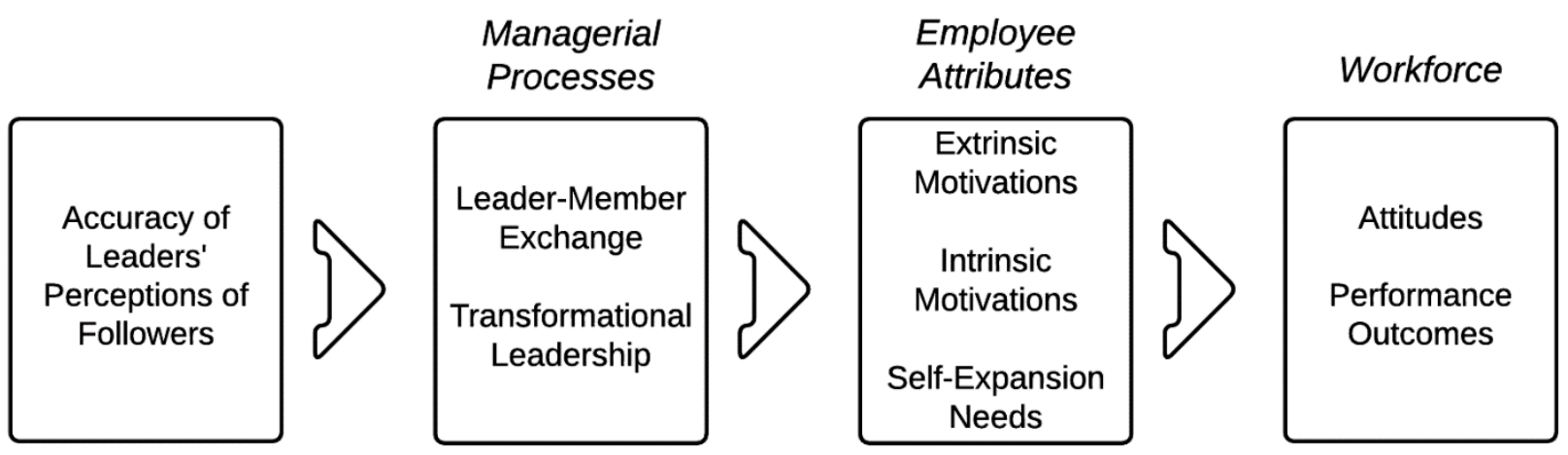

\section{Achieving Accurate Perceptions}

Making judgments of others is more intensive than the layperson may believe, and much research has been undertaken to illuminate the process by which it occurs (Back \& Nestler, 2016). The Realistic Accuracy Model (RAM; Funder, 1995, 2012) was developed to explicate the process through which accurate judgments come to be made. Specifically, the RAM outlines four steps which must occur for attaining accuracy in the perceptual process - relevance, availability, detection, and utilization - which are related multiplicatively. Specifically, if one or more of these steps is not successfully traversed, the expected level of accuracy is nil (Funder, 1995, p. 659).

To exemplify this point, let us conceptually work through the judgment process. First and foremost, relevant information must exist - be it behavior, attitudes, etc. If the information that exists is not relevant to the phenomena of interest, it does not inform impressions meaningfully. Second, relevant information must be available externally and for perception by the judge. Without information being available, valid cues on which impressions can be based are absent. These two stages, relevance and availability, are attributed to the target of the impending judgments. Completion of these stages will allow the judgecentered steps to occur - detection, and subsequent utilization, of relevant and available information. To this point, if relevant information is available and the judge does not attend to it, accurate impressions, again, will not be had. Finally, even if the first three steps have, at least partially, been completed, the judge must still properly utilize that relevant information that was detected. While this seems simple enough, if one is unable to utilize, or improperly applies, that information in his or her judgments, accuracy will not be achieved (Funder, 2012).

Expanding upon the RAM framework, there are several factors that can attenuate the level of accuracy achieved. Specifically, there are four primary moderators which "makes accuracy more or less likely" by interacting with one or more stages of the RAM - good target, good judge, good information, and good trait (Funder, 1995, p. 660). As we will argue, particularly important to being an effective manager/leader is to also be a good judge. However, some question if people vary in their ability to accurately perceive others (Allik, de Vries, \& Realo, 2016). Nonetheless, there is much evidence for individual differences in the ability to, on average, make accurate judgments. Indeed, a variety of personality, behavioral, and situational factors are related to making accurate personality judgments. Specifically, higher accuracy has been found for individuals who have a greater tendency for perspective-taking and empathy (Bernstein \& Davis, 1982; Colman, Letzring, \& Biesanz, 2017), hold higher levels of dispositional intelligence (Christiansen, WolcottBurnam, Janovics, Burns, \& Quirk, 2005), are motivated (Biesanz \& Human, 2010; Taft, 1955), and possess more social skills, are agreeable, and report being well-adjusted (Letzring, 2008). Most noteworthy herein is the relation between ones perspective-taking propensity and judgmental accuracy (Bernstein \& Davis, 1982; Colman et al., 2017), and how perceptions, accurate or not, are utilized within the leadership process (Lord \& Maher, 1993). 
Perspective-taking is a process by which one temporarily takes a point-of-view other than his or her own in an effort to gain insight (Galinsky, Maddux, Gilin, \& White, 2008). This process can occur physically by changing one's position to gain another viewpoint or cognitively by imagining the conditions which another entity is experiencing. Regardless of the form of gaining perspective, many benefits are gained from the process. For example, it has been found that the process of perspective-taking reduces stereotype use (C.S. Wang, Ku, Tai, \& Galinsky, 2014), provides an advantage during negotiation (Galinsky et al., 2008), and facilitates interactions among in-group and out-group members (Galinsky \& Moskowitz, 2000; C. S. Wang, Tai, Ku, \& Galinsky, 2014). Furthermore, when in a position, or simply holding a feeling, of power, perspective-taking can increase the fairness of decisions through the solicitation and use of others views, and such inclusion of alternative points-of-view also promotes decision accuracy (Galinsky, Magee, Rus, Rothman, \& Todd, 2014). In sum, perspective-taking is not only related to being a good judge (Bernstein \& Davis, 1982; Colman et al., 2017), but also to achieving positive social and organizational outcomes.

Why are accurate judgments of personality, motivations, and attitudes important? A brief examination of the literature paints a clear picture - these characteristics have a meaningful relation with employee behavior within organizations (Barrick \& Mount, 1991; Judge, Heller, \& Mount, 2002; Judge \& Ilies, 2002; Judge, Rodell, Klinger, Simon, \& Crawford, 2013; Judge, Thoresen, Bono, \& Patton, 2001; Locke \& Latham, 2002). As such, accurately perceiving and understanding followers is a necessary, but not alone sufficient, implicit requirement for leadership. Remarkably, however, management and leadership scholars have yet to theoretically or empirically address this assumption. Thus, we will highlight critical linkages between leaders' judgment accuracy and their relations with followers. Specifically, we explicate how leaders' ability to influence the behaviors and attitudes of followers is facilitated by forming accurate perceptions of personality, motivations, and attitudes, and then properly utilizing that knowledge in their leadership activities.

\section{ORGANIZATIONS AND BEHAVIORS WITHIN THEM}

At the most basic level, organizations are created to pool resources (human, financial, otherwise) toward a common objective (Blau \& Scott, 1962). Religion brings people together to connect with a deity; political parties rally together to translate commonly held positions into legislation; businesses emerge to provide desired goods and/or services. However, even when formed with a clear and common objective, such views and purposes can, and often do, change. Moreover, as time passes, those within a given organization can come to misunderstand the ideas and views on which the organization was founded (Ouchi, 1980). Thus, decision makers within organizations need to be cautious when interpreting the behaviors of constituents, as their behaviors and attitudes are not only a function of their motivation, selfefficacy of requisite skills, and personality (Cerasoli, Nicklin, \& Ford, 2014; Judge \& Ilies, 2002; Stajkovic \& Luthans, 1998), but also their perception of the organizational vision, culture, and objectives (Bass \& Avolio, 1993; Bass \& Riggio, 2006; Schein, 2004).

\section{Organizational Behaviors and Attitudes}

Organizational behavior consists of "human behavior in organizational settings, of the interface between human behavior and the organization, and of the organization itself" (Griffin \& Moorhead, 2010, p. 3). While all three levels - micro, conduct of individual persons; meso, team or group behaviors; and macro, organizational actions - are certainly important to achieving a visionary state, the micro level will be the focus herein. Moreover, we consider attitudes subsumed within organizational behaviors because they represent hidden (i.e., only accessible to the individual who holds them) views, beliefs, and/or intentions that influence the manifestation of behaviors (Ajzen, 2001; Glasman \& Albarracin, 2006).

There are countless work attitudes and behaviors, but in an effort to maintain focus in this article, we only discuss a select few. Specifically, trust (Colquitt, Scott, \& LePine, 2007), job satisfaction (Judge et al., 2001), job performance (i.e., quantity and quality of outputs), organizational citizenship behaviors (e.g., working beyond scheduled hours, assisting coworkers; Koys, 2001; Organ, 1997; Smith, Organ, \& Near, 
1983; Van Dyne, Graham, \& Dienesch, 1994), and organizational commitment and turnover intentions (Shore \& Martin, 1989) will be reviewed.

Also important to the manifestation of behaviors and attitudes at the micro level are individual difference characteristics - most centrally, personality. Indeed, Judge and his colleagues have found personality, particularly the lower-order facets seen using the trait theory approach, to be meaningfully predictive of behavior, attitudes, and performance outcomes (Judge, Klinger, Simon, \& Yang, 2008; Judge et al., 2013). As such, personality is discussed in greater detail below with consideration of its relation to work behaviors and attitudes.

\section{PERSONALITY AND INDIVIDUAL DIFFERENCES}

The discipline of personality psychology is aimed at understanding the whole person - how people, situational constraints, and resulting behaviors interact to allow distinction between individuals. With this purpose in mind, personality is an "individual's characteristic patterns of thought, emotion, and behavior together with the psychological mechanisms - hidden or not - behind those patterns" (Funder, 2001, p. 198). This broad definition provides room for many theoretical approaches to understanding individual differences. However, for the purpose of this paper, two domains of particular interest - the Big Five taxonomy and the Self-Determination Theory (SDT) of motivation - are reviewed below and followed by dialog of the levels on which behavior is expressed.

\section{The Big Five Taxonomy}

It has been cogently stated that "in order for any field of science to advance, it is necessary to have an accepted classification scheme for accumulating and categorizing empirical findings" (Barrick \& Mount, 1991, p. 23). The Big Five taxonomy of personality provides such a scheme, and has received widespread acceptance (albeit not universally) by personality scholars (Goldberg, 1993). The five trait domains are Openness (involves imagination, insightfulness, and possessing varied interests), Conscientiousness (describes attributes such as organization, planning, and being thorough), Extraversion (associated with being energetic, talkative, and assertive), Agreeableness (describes kind, affectionate, and empathetic tendencies), and Neuroticism (propensity to be anxious, moody, and/or tense; Srivastava, 2016).

Central to this paper are the relations among these domains and organizational behaviors and attitudes. One of the most cited studies on this relation (Barrick \& Mount, 1991) found that the Big Five factors relate to job performance, but they do so differentially - except for Conscientiousness. In fact, across three performance criteria in five occupational groups Conscientiousness was a reliable correlate. Further, a later published study (Judge, Higgins, Thoresen, \& Barrick, 1999) found that the Big Five traits were reliably related to career success, even when controlling for intelligence. More specifically, job satisfaction and income level were positively correlated with Conscientiousness. Beyond this, income level was also negatively related to Neuroticism. Similarly, a more recent meta-analysis (Judge et al., 2002) supported this notion that Conscientiousness was related to job satisfaction (estimated true correlation $(\rho)=.26$ ).

Expanding upon the utility of the Big Five taxonomy in the workplace from a lifespan perspective, data from the Mills Longitudinal Study indicated that three of the Big Five factors (Conscientiousness, Extraversion, and Openness) were predictive of key work-related outcomes in women over a period of 50 years. Specifically, the three personality traits measured at 21 years of age were predictive of a diverse range of employment outcomes across the lifespan. Openness was positively related to the number of creative accomplishments; Extraversion was related to the attainment of higher status careers; Conscientiousness was related to commitment toward life duties (e.g., family, work; George, Helson, \& John, 2011).

Overall, there is a substantial body of evidence - cross-sectional, longitudinal, and meta-analytic - for the utility of the Big Five traits as indicative of workplace attitudes and behaviors. However, it does not complete the picture of the whole person (Funder, 2001). In fact, motivation is an important individual difference. While it has been meta-analytically found that Neuroticism, Extraversion, and Conscientiousness are predictive of motivation (Judge \& Ilies, 2002), there are also situational and social 
factors that influence motivation. Thus, one meta-theory and several $s u b$-theories of motivation, which have been shown to be relevant to workplace behaviors and attitudes, are reviewed in the proceeding section.

\section{Motivation}

Motivation is the term used to capture the broad latent construct of what energizes one to initiate goaloriented behaviors (Ryan \& Deci, 2000), and shapes the form, duration, intensity, and focus of those behaviors (Pinder, 2008). In essence, motivation is a core element to the attainment of objectives - be it personal-, relationship-, or work-oriented. Within the field of management and leadership, motivation is an essential piece (mindset) of the informal performance equation (i.e., Opportunity $\mathrm{x}$ Abilities $\mathrm{x}$ Mindset $=$ Performance Output; Steers, Mowday, \& Shapiro, 2004). Although framed broadly here, "motivation is hardly a unitary phenomenon; people have not only different amounts, but also different kinds of motivation" (Ryan \& Deci, 2000, p. 54). As such, several perspectives on the construct of motivation, which we deem relevant to this paper, are discussed under the framework of the meta-theory of SDT (Deci \& Ryan, 2000; Ryan \& Deci, 2008).

\section{$S D T$}

A fundamental tenant of SDT is that humans have basic psychological needs that provide nourishment for psychological wellness, growth, and integrity. Behavior is posited to be a function of the manner in which one construes stimulus inputs (either external or internal); and, the construal of those inputs is determined by their fulfillment of the basic psychological needs (Ryan \& Deci, 2008). The basic, innate psychological needs as proposed by SDT are autonomy (volition and congruence to the self of undertaken actions), competence (sense of efficacy in one's actions), and relatedness (sense of belonging in and connectedness with one's social environment; Deci \& Ryan, 2000). Conceptually, it is these needs, or the regulation (internal/external) of these needs, that affects the quality of motivation one experiences (Gagné $\&$ Deci, 2005).

Intrinsic vs. Extrinsic Incentivization. Motivation is commonly dichotomized as either intrinsic, defined as the undertaking of an action simply because it is perceived as enjoyable or interesting, or extrinsic, in which some "separable" consequence results, such as money or social status (Ryan \& Deci, 2000). Conceptualized from the SDT framework, "people will become more or less [intrinsically motivated] in activities as a function of the degree to which they experience need satisfaction while engaging in those activities" (Deci \& Ryan, 2000, p. 233; emphasis added). The same holds for extrinsic motivation, but the need satisfaction would stem from, or occur after, the action. Given this nature of extrinsic motivation, it will subsequently be reviewed in the context of goals and self-expansion.

In regards to intrinsic motivation, it has been found that having choice in activity and time allotted for tasks produce greater intrinsic motivation than being assigned to activities with a predetermined time allotment (Patall, Cooper, \& Robinson, 2008; Zuckerman, Porac, Lathin, Smith, \& Deci, 1978), which is congruent with the need for autonomy (Ryan \& Deci, 2017). More importantly, however, is that intrinsic motivation is positively related to exerted effort, perceived competence, and task performance (Patall et al., 2008). Additionally, a recent meta-analytic review (Cerasoli et al., 2014) indicated that intrinsic motivation is more predictive of quality than quantity of performance outcomes. Furthermore, aligned with the view of Ryan and Deci (2000), it was found that intrinsic and extrinsic motivation are not at opposite ends of a single spectrum, but rather two separable influences of performance motivation that jointly predict variation in performance outcomes (Cerasoli et al., 2014).

Goals. Goal setting theory has a rich tradition within industrial and organizational psychology, training and development, and human resource management and is considered an "open" theory. This means that the theory is amenable to integration with other theories (Locke \& Latham, 2006), such as SDT. In fact, SDT is well suited for the study of goals as a source of extrinsic motivation (Ryan \& Deci, 2008). While goals provide a "separable" consequence, they do provide a direction for action (Locke \& Latham, 2002), which could address the need for autonomy (Deci \& Ryan, 2000) - especially if self-selected. Furthermore, there are many moderators and mediators of the efficacy of goals. For instance, precise, hard goals generally lead to greater task performance (Locke \& Latham, 2006). 
This effect of goal difficulty maps nicely onto the competence need outlined in SDT (Deci \& Ryan, 2000). This is especially true when one holds a "learning orientation", as the goals are viewed as challenging as opposed to threatening (Locke \& Latham, 2006). Potentially, this is an area where both intrinsic and extrinsic motives could simultaneously be at play as suggested by Cerasoli et al. (2014). That is, the goal is extrinsically motivating as a means to a future consequence, but also intrinsically as a method to personal growth (Deci \& Ryan, 2000) by expanding one's self-concept (Leary, 2007).

Self-Expansion. The self-expansion model posits that individuals have a desire to expand the self through a variety of activities (Aron \& Aron, 2009), which aim to increase efficacy "by increasing the physical and social resources, perspectives, and identities that facilitate achievement of any goal that might arise" (Aron, Aron, \& Norman, 2001, p. 478). In this regard, self-expansion motivation is aimed at attaining the resources needed to achieve goals. Applying this to SDT (Deci \& Ryan, 2000; Ryan \& Deci, 2008), self-expansion serves as an avenue to meet the need for competence by gaining requisite skills and knowledge to be effective. Further, it can help alleviate the need for relatedness as expanding the self through relations with others is commonplace (Aron, Lewandowski, Mashek, \& Aron, 2013). Finally, the need for autonomy is confronted as self-expansion is marked by an approach motivation for increasing resources in domains that one perceives as novel (Mattingly, McIntyre, \& Lewandowski, 2012).

Although much of the research on self-expansion has focused on close relationships (Aron et al., 2001; Aron et al., 2013; Mattingly et al., 2012), its recent application to the work environment has been promising. While it has been found that work contributes to one's social status and identity (Jahoda, 1981), it was found that repositioning to a less self-expanding job is related to decreased self-concept clarity and selfesteem (McIntyre et al., 2014). Beyond this, higher levels of workplace self-expansion is predictive of job satisfaction, turnover intentions, and affective commitment (Gray, McIntyre, Mattingly, \& Lewandowski, 2015), and this holds after controlling for demographics, tenure in the position, and monetary compensation (McIntyre et al., 2014).

\section{Levels of Behavioral Expression}

There are three levels at which human behavior is theorized to occur (Clawson, 2002). Level 1 (L1) is visible, objectively measurable behavior - the words that people speak, the actions they undertake. This is certainly the most salient level of behavior exhibited. Beyond L1, at level 2 (L2), is the conscious thought of the individual. While it is possible to infer an individual's thought process from his or her overt behavior, the conclusions are subjective. Finally, espoused Values, Assumptions, Beliefs, and Expectations (VABEs) held by individuals reside at the semi-conscious level (L3). These VABEs are culturally engrained elements of the self that have been developed over a long period of time (Schein, 2004); they represent "the way [one thinks] the world is or should be" (Clawson, 2002, p. 26).

An explicit objective of a supervisor within an organization is to influence followers' expression of behaviors and attitudes toward supporting the organization's mission, vision, and attainment of goals. Given these levels at which behavior and attitudes can be expressed (Clawson, 2002), it is crucial that the whole individual is considered when trying to understand and influence manifested behaviors and the attitudes that drive them. To this point, supervisors have a wide array of tactics at their disposal, of which some address behavior at L1, L2, or L3. For instance, a supervisor could develop policies that simply constrain (by reward or punishment) visible and explicit behaviors. Getting below the surface, a manager can attempt to influence, or even change, followers' conscious thoughts and mental behavior through additional training, communicative processes, etc. Alternatively, the invested, and hopefully ethical, leader can attempt to challenge and ultimately change follower VABEs (Clawson, 2002). Conceptually, it is the L3 elements that affect those at L2, and then those aspects ultimately manifest in the visible behavior exhibited at L1 (Clawson, 2002; Schein, 2004). Stated differently, "it is typically people's feelings, beliefs, motives, and goals, and the perceived environment within which these feelings, beliefs, motives, and goals arise, that organize subsequent behavior" (Ryan \& Deci, 2008, p. 655). 


\section{Behaviors and Attitudes as a Function of VABEs}

Humans have a desire to find order in an otherwise chaotic environment. This need is not lost on the leader, yearning to understand the patterns of attitudes and behaviors exhibited by his or her followers. However, this desire is not just directed toward those around us, it is also desired for a true understanding of ourselves. Enter the topic of personality coherence (Carvone, 1997; Carvone \& Shoda, 1999; Sheldon \& Kasser, 1995) - the degree to which our behaviors can be said to exist within a single rational framework.

While one is unable to change the past, and that includes his or her behavior, we are able to change our attitudes in response to behaviors, which were inconsistent with attitudes that we hold. For the sake of maintaining personality coherence, this ability to adapt/change one's attitudes is valuable. Moreover, it provides an avenue for leaders to affect change in followers' behaviors and attitudes. A Zig Ziglar quote emphasizes this point: "You cannot perform in a manner inconsistent with the way you see yourself." We briefly describe a classic study conducted by Festinger and Carlsmith (1959) to provide context on this point.

Participants were asked to report to the next participant, who was actually a research assistant, that the boring and mundane experimental task they just completed was actually interesting, and in exchange they would receive compensation - either $\$ 1$ or $\$ 20$. Interestingly, those receiving minimal payment (\$1 rather than \$20) later rated the experimental task as significantly more interesting. Because individuals typically act in accord with their belief system, attitudinal changes will occur in response to cognitive dissonance, which arises when one acts out of coherence with his or her self-view without a rational reason (e.g., \$20 for a simple white lie; Festinger \& Carlsmith, 1959).

The existence of this phenomenon provides two distinct avenues to influence individuals to hold desirable attitudes and exhibit positive behaviors. First, create appropriate value systems that allow individuals to avoid cognitive dissonance (Kerr, 1995). Or two, align follower VABEs with those of the organization. Regardless of the path of influence chosen for initiating desirable behaviors and attitudes, some degree of leadership, as opposed to management, is required. Thus, in the next section of this paper the topic of leadership is broached. First, the distinction between management and leadership is presented. Then, two well-known and researched philosophies - Full Range Leadership Theory and Leader-Member Exchange Theory - are outlined. Specifically, arguments are made for how coming to accurately understand followers VABEs provides an avenue for eliciting behaviors and attitudes that advance the organizational mission.

\section{LEADERSHIP}

\section{Management vs. Leadership ${ }^{1}$}

To the layperson, the terms management and leadership are synonyms; they are used interchangeably. However, for the purpose of this paper, the distinction between these constructs is important. While leadership has been a topic of interest for millennia (for example Plato, Aristotle, and Sun Tzu all broached the topic), it was not until the onset of the industrial revolution in the $19^{\text {th }}$ century that the concept of management was introduced. With an increased need to organize, plan, and control the production process, managers used a scientific approach to increase efficiency (Toor \& Ofori, 2008). Conversely, leadership holds a lush tradition of aligning vision among organizational members, increasing their performance motivation, and enabling followers by providing the means (e.g., autonomy, skills) for performing not only to, but also beyond, expectations (Bass, 1985; Bass \& Riggio, 2006). Indeed, Kotter (2001, p. 90) made this point by stating: "Management is about coping with complexity. Leadership, by contrast, is about coping with change."

Because of these distinctions in why leadership versus management emerges within an organizational context, there are meaningful differences in how power is obtained (Zaleznik, 1977). As Toor and Ofori (2008, p. 64) noted, "leadership involves power by influence [while] management involves power by position." Most notably, leaders can emerge at any level of an organization, with or without formal authority. Conversely, managers, by definition, require formal authority, be it monetary resources, hiring/firing privileges, etc. Although the purpose and source of power vary between leaders and managers, 
both are necessary for successfully fulfilling the mission of any organization (Hay \& Hodgkinson, 2006). Leadership plays a crucial role in determining, and ensuring understanding of, the organizational vision; management on the other hand ensures that financial performance through product/service quality is sustained while progressing to the visionary state (Toor \& Ofori, 2008). This last point on the need for both managers and leaders within an organization also makes salient another difference - time orientation. Managers most often focus on the here and now, while leaders typically hold a future orientation especially for growth (Thoms, 2004).

\section{Full Range Leadership Model}

Burns (1978) first introduced the concept of transforming leadership. Using that initial conceptualization, Bass (1985) broadened it to describe a model of full range leadership and provided initial empirical support. As the name implies, there is a range of tactics that can be used to influence others. These include inactive-passive strategies (i.e., laissez-faire), error management and contingent reward (i.e., transactional), all the way to full incorporation of the individual (i.e., transformational; Northouse, 2010). Each of these will be considered in turn, with special attention to transformational leadership.

\section{Laissez-Faire Supervision ${ }^{2}$}

It is interesting that laissez-faire is traditionally dubbed a type of leadership, as it is defined as the absence thereof. Individuals exhibiting the laissez-faire style are people in a position of power, but lack enthusiasm for leading, and even managing, others. These individuals are inactive - there is a clear lack of interaction with their subordinates. This point stands true even when there are delays, production errors, or other problems that occur which necessitate involvement by a supervisor (Bass, 1985; Bass \& Riggio, 2006). Overall, this type of non-leadership is never a useful method to influencing attitudes and behaviors crucial to attaining an organizations vision. ${ }^{3}$

\section{Transactional Management ${ }^{4}$}

As the supervisor becomes more active, the leadership process becomes more transactional in nature. Under the umbrella of transactional management, supervisors exhibit behaviors that can vary in their degree of interaction. Specifically, three distinct subtypes of transactional processes exist - passive management by exception, active management by exception, and contingent reward systems (Avolio, Bass, \& Jung, 1999; Bass, 1985; Bass \& Riggio, 2006; Northouse, 2010). Ultimately, this category of leadership techniques is aimed at maintaining the status quo.

Management by Exception. Just beyond the laissez-faire supervisor is the manager who remains inactive until failures occur and require intervention (Bass \& Riggio, 2006). In such situations, the manager will issue a correction through reprimand to the individual(s) responsible for the particular mishap. This influence tactic is rather reflexive and thus termed management by exception - passive. Alternatively, management by exception - active is a management style in which the supervisor will actively investigate procedural areas in which errors can occur. Once identified, methods are devised to actively monitor for, and correct, errors (Northouse, 2010).

Contingent Reward. Contrasting, but in the same domain as management by exception is contingent reward (Bass, 1985; Bass \& Riggio, 2006). Under this scheme, managers use reward systems, hopefully ones that are properly structured and communicated (see Kerr, 1995), to maintain the output of desirable behaviors and attitudes by subordinates (Northouse, 2010). Put in psychological terms from the learning literature, management by exception - active (and passive to a lesser extent) is a punishment-based system, while contingent reward is a reinforcement-based system. Both of which, from the SDT point of view, results in sub-optimal motivation levels over time (Ryan \& Deci, 2017).

\section{Transformational Leadership}

Again, the concept of transforming leadership was first introduced by Burns (1978), specifically in a political-historical context. As expanded upon by Bass (1985), this type of leadership emphasizes intrinsic motivation and follower development, which has made it one of the most prominent theories over the past 
quarter century (Bass \& Riggio, 2006). Indeed, Judge and his colleagues have noted that since the delineation of transformational leadership (circa 1990) there have been more articles published with the keywords "transformational leadership" or "charismatic leadership" than all other popular theories combined (Judge \& Bono, 2000; Judge \& Piccolo, 2004). Although transformational leadership is but one dimension of the Full Range Leadership Model, Bass, Avolio, and their colleagues have argued that four distinct factors exist (Avolio et al., 1999; Bass, 1985; Bass \& Riggio, 2006), each of which is briefly described in turn.

Idealized Influence. Transformational leaders are often seen as a role model by followers and are thus admired (Bass \& Riggio, 2006). Because of the transformational leader's propensity for ethical behavior, followers deeply respect and place trust in them (Northouse, 2010). Stemming from this respect and trust, leaders high in idealized influence act more consistently with the vision they set forth, even when doing so requires taking risks. Ultimately, this component of transformational leadership is comprised of two separable aspects: behaviors and attributions (Bass \& Riggio, 2006). Does the leader act consistently within the proper ethical boundaries (behavior)? Do followers describe the leader using higher-level descriptions, such as persistent, truthful, or determined (attribution)? The point here is that transformational leaders can influence followers in an idealized (or charismatic) way through (a) their behaviors, (b) the way they are perceived, or (c) an interaction of behaviors and follower perceived attributions.

Inspirational Motivation. In the process of influencing followers, the transformational leader provides clear goals with which followers are able to identify (Northouse, 2010). A clear vision is presented, which helps provide a connection between the followers and the organizational purpose and inspires followers to act in ways that propel them toward the desired end state (Bass, 1985; Bass \& Riggio, 2006). Although the purpose is clear, the degree to which it challenges followers is also important. As describe previously, the process of self-expansion can be a strong motivator (Aron \& Aron, 2009; Aron et al., 2001). Thus, when the path to attaining the clearly presented organizational vision is challenging and an opportunity for growth, it is seen as motivating. Ultimately, when a clear vision is presented in alliance with high expectations for performance, followers tend to exert more time and effort in the tasks (Locke \& Latham, 2002). Further, encouragement and optimism by the leader about the visionary state increase followers' belief in their abilities and excitement about expanding their current skill set (Gray et al., 2015).

Intellectual Stimulation. A core difference mentioned above during the discussion about the distinction between a leader and a manager is the time orientation (Thoms, 2004) - focus on the here and now (manager) or the future through growth (leader). It is in this factor of transformational leadership that this essential difference is manifested. The transformational leader challenges the follower to grow (Bass \& Riggio, 2006). They challenge followers' VABEs, encourage calculated risk taking, and intentionally solicit followers' perspectives and ideas (Clawson, 2002; Schein, 2004). In this process, leaders develop individuals' ability to think independently and encourage creativity (Northouse, 2010). Learning is viewed as an important skill in and of itself, thus unexpected situations are seen as opportunities for growth (Gray et al., 2015). In this regard, the leader is extremely active in the process by creating opportunity and providing feedback.

Individualized Consideration. In a similar vein as intellectual stimulation, transformational leaders consider each individual follower as unique and possessing a distinct skill set. In this regard, each follower's needs are distinct. It is exactly this point that makes explicit the need for leaders to accurately perceive their followers' personality traits and motivations. In so doing, leaders will be able to customize their mentorship to the unique characteristics and VABEs of each follower (Bass, 1985; Bass \& Riggio, 2006). Over time, this process allows development to occur through a series of challenging tasks that provide opportunities for growth. And during that process, the leader provides the necessary support through quality interactions (H. Wang, Law, Hackett, Wang, \& Chen, 2005). Binding this component to the previous ones, and as a transformational process in general, leaders celebrate and respect successful follower growth and acknowledge their individual contribution to the attainment of the organizational vision (Bass \& Riggio, 2006).

A major theoretical element not captured by the full range leadership model is the quality of the leaderfollower relationship. However, this element of the leader-follower dynamic has been studied, which has 
produced a separate, but related theory - Leader-Member Exchange (LMX; G. Wang, Oh, Courtright, \& Colbert, 2011). While it is a distinct line of inquiry, the LMX process is particularly relevant to transformational leadership, and chiefly the individualized consideration and idealized influence factors therein (Deluga, 1992). Given this, LMX theory will now be discussed.

\section{LMX Theory}

First dubbed Vertical Dyad Linkage, LMX theory proposes that leaders have a different relationship with each of their followers (Dansereau, Graen, \& Haga, 1975; Graen \& Uhl-Bien, 1995). Thus, the quality of the relationship serves an important function in the leader's ability to influence followers, and the tactics they use to do so (Harris, Wheeler, \& Kacmar, 2009). Specifically, followers who experience higher quality LMX will be privy to greater information, more communication, and direct influence (Dansereau et al., 1975). Indeed, as Deluga (1992) noted, "transformational leaders may foster the formation of high-quality relationships and a sense of a common fate with individual subordinates; while in a social-exchange process, subordinates strengthen and encourage the leader" (pp. 243-245). This observation draws a direct link between LMX and the transformational leadership process described in the Full Range Leadership Model. Therefore, the next few paragraphs outline the impact of transformational leadership on behaviors and attitudes, with consideration of LMX quality.

\section{Transformational Leadership, LMX Quality, and Behaviors and Attitudes}

The enormity of the literature on transformational leadership provides evidence of its perceived importance, for scholars and practitioners alike. Indeed, meta-analyses (Judge \& Piccolo, 2004; G. Wang et al., 2011) have provided strong evidence of transformational leadership's validity. In particular, the recent review by G. Wang and colleagues (2011) found that transformational leadership was positively related to performance across three individual level criterion (task, contextual, and creative) as well as teamand organizational-level performance. Beyond these correlational findings, the use of transformational leadership over transactional techniques was found to increase trust in, and value congruence with, the leader, which were then predictive of behaviors (quality and quantity of outputs) and attitudes (job satisfaction; Jung \& Avolio, 2000). Much like the effect of intrinsic motivation on quality and quantity of performance (Cerasoli et al., 2014), transformational leadership had a negative relation with quantity, but a positive relation with quality of performance (Jung \& Avolio, 2000). Investigating the factors of transformational leadership in a field experiment, Barling, Weber, and Kelloway (1996) found that managers who were instructed to focus on increasing intellectual stimulation, individualized consideration, and charisma toward their followers produced significant increases to organizational commitment and financial performance over a 5 -month period.

More interesting than the simple effects of transformational leadership on behaviors and attitudes, are the factors through which these results occur (mediating variables) or elements that attenuate the relationship (moderating variables). As noted earlier, the quality of the leader-member relationship is a central consideration. Indeed, it has been reliably found that LMX quality mediates the relation between transformational leadership and the resulting attitudes and behaviors of followers (Dulebohn, Bommer, Liden, Brouer, \& Ferris, 2012; H. Wang et al., 2005). However, transformational leadership is still predictive of performance outcomes after controlling for LMX quality (Krishnan, 2005). Therefore, each of these two leadership processes uniquely contributes to the influencing of followers.

Creating a basic theoretical model from these findings helps the existing research to be more easily understood (see Figure 2). For instance, it has been found that followers' trust (Podsakoff, MacKenzie, Moorman, \& Fetter, 1990), organizational citizenship behaviors, and communication quality (Boerner, Eisenbeiss, \& Griesser, 2007) mediated the relation between transformational leadership and follower performance. Because these factors are related to, or a function of, LMX quality (Ilies, Nahrgang, \& Morgeson, 2007), such findings fit nicely with the model of LMX partially mediating the transformational leadership-follower performance link. 


\section{FIGURE 2}

\section{BASIC THEORETICAL MODEL OF TRANSFORMATIONAL LEADERSHIP PREDICTING ORGANIZATIONAL BEHAVIORS AND ATTITUDES PARTIALLY MEDIATED THROUGH QUALITY OF LEADER-MEMBER EXCHANGE}

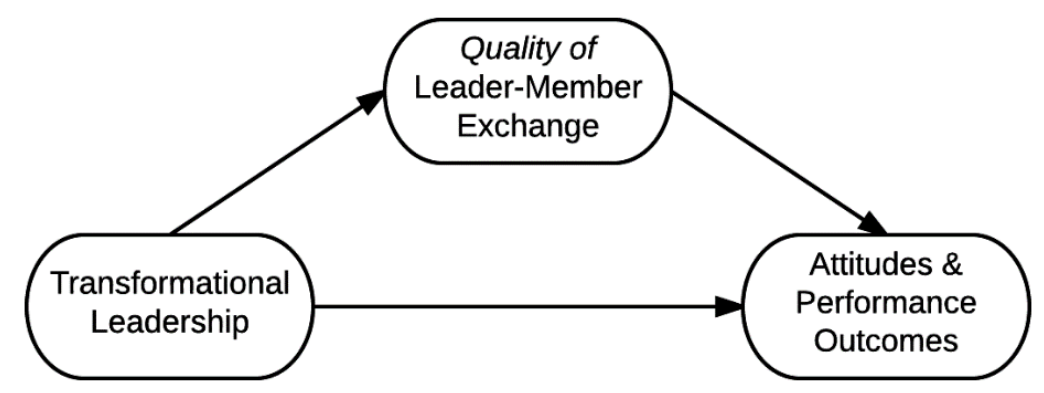

In a similar vein, follower empowerment has been found to partially mediate the relation between LMX quality and employee behaviors (task performance and withdraw) and attitudes (e.g., job satisfaction; Aryee $\&$ Chen, 2006; Harris et al., 2009). Thus, the feeling of task efficacy along with autonomy provided by transformational leadership processes is important to influencing outcomes. This makes salient the importance of motivation, particularly through the SDT lens and innate psychological needs. To this point, self-expansion has been linked to transformational leadership, LMX, job satisfaction, affective commitment, and turnover intentions (Gray et al., 2015). Thus, it might be the case that self-expansion serves as a key node in a path model for behaviors and outcomes (see Figure 3).

FIGURE 3

\section{THEORETICAL PATH MODEL OF TRANSFORMATIONAL LEADERSHIP PREDICTING FOLLOWER SELF-EXPANSION PARTIALLY MEDIATED THROUGH QUALITY OF LEADER-MEMBER EXCHANGE, WHICH IS THEN PREDICTIVE OF ATTITUDES AND PERFORMANCE OUTCOMES OF FOLLOWERS}

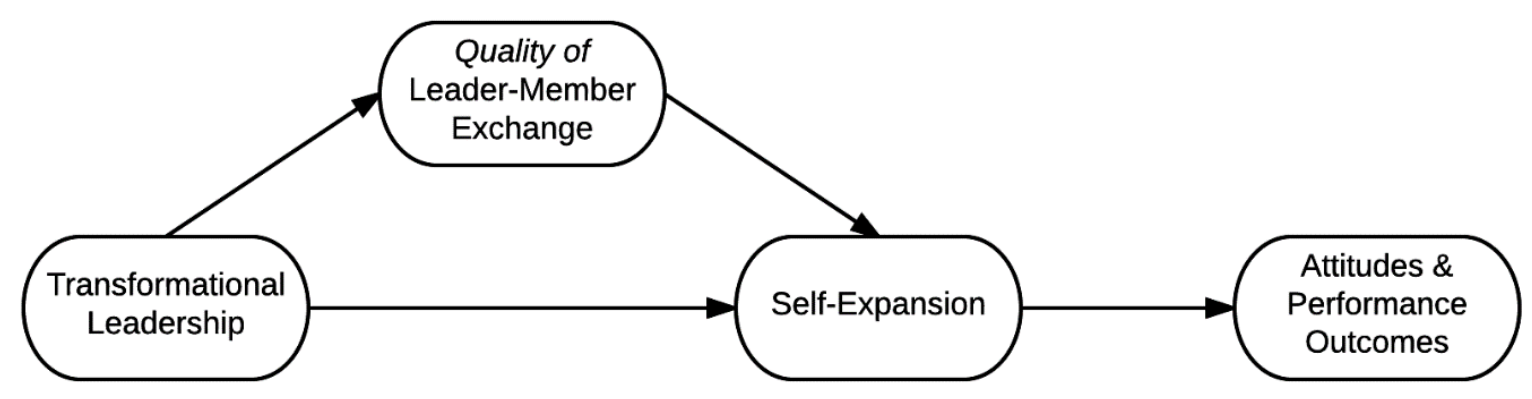

\section{Understanding Leader-Follower Relations}

By this point it should be clear that interpersonal relations are at the core of eliciting desired attitudes and behaviors from followers. Important to such interpersonal processes are two self-motives - selfenhancement and self-verification. Leary (2007) notes that individuals are motivated to "maintain or increase the positivity (or decrease the negativity) of one's self-concept" (p. 319), but are also driven to self-verify by soliciting "information that is consistent with their existing views of themselves" (p. 324). These two seem to be in line with one another; however, issues can arise when one views his- or her-self less positively than others do. This holds particularly true in an organizational context, where a leader's perceptions of the follower are more positive than his or her self-view. Such a situation could cause suboptimal performance to manifest, possibly due to the follower's inadequate self-efficacy. Nonetheless, when there is a balance between leaders perceptions of the follower and the follower's self-view, job performance, organizational commitment, and job satisfaction are better predicted (Cogliser, Schriesheim, 
Scandura, \& Gardner, 2009). Such a finding suggests that accuracy in perceiving followers' self-concept may aid in resolving the disparate views, and even provide the necessary foundation for initiating change in followers' self-views to better align with the organizational vision, mission, and goals.

Indeed, it has been suggested that leaders can produce enduring changes in followers' working selfconcept (Lord, Brown, \& Freiberg, 1999). As noted earlier, two components of transformational leadership - individualized consideration and inspirational motivation - are likely to be especially influential. Assuming fairly accurate perceptions of a follower's personality traits, motivations, and VABEs, leaders can customize a plan of action to ensure the follower's understanding and acceptance of the organizational vision, thus inspiring growth (e.g., self-expansion) through the manifestation of behaviors and attitudes imperative to the attainment of organizational goals. Ultimately, it should be the case that such a progression will promote congruence between the follower's self-concept with the way in which the leader sees him or her (Bono \& Judge, 2003). Alluding to this need to truly understand followers, Burns (1978) stated: "the transforming leader recognizes and exploits an existing need or demand of a potential follower" (p. 4, emphasis added). However, the importance of accurately perceiving and coming to understand followers' personality attributes, motivations, and VABEs has not been expressed as a central path for providing leadership and developing quality relationships with followers.

Because leadership is a stage-like developmental process - from strangers to acquaintances, and finally relational partners (Graen \& Uhl-Bien, 1991) - there is a fundamental dependence upon person perception and perspective-taking processes. That is, one's initial judgments of another serve as the basis on which further interactions will be structured (Asch, 1946; Back \& Nestler, 2016), while the use of perspectivetaking can reduce the amount of stereotyping in use (C. S. Wang, $\mathrm{Ku}$, et al., 2014) and is positively correlated with accuracy in the judgment process (Colman et al., 2017). Thus, based on the premise that VABEs are the most effective and long lasting means by which leaders influence followers to perform desired work behaviors or hold desirable attitudes (Clawson, 2002), it is imperative that judgments are accurate. Furthering this argument alongside the prior discussion of the three levels of influence, the focus of the remainder of this paper is on how a leader's accurate understanding of the whole follower will enhance his or her effectiveness.

\section{LINKING LEADER PERSON PERCEPTION ACCURACY WITH BEHAVIORS AND ATTITUDES}

Intentional or not, Burns (1978) identified the importance of the judgmental accuracy process with the following quote: "The transforming leader looks for potential motives in followers, seeks to satisfy higher needs, and engages the full person of the follower" (p. 4). First, "looks for potential motives" emphasizes the idea that leaders actively attempt to detect cues that inform them about the motives behind followers' behaviors and attitudes. Second, "seeks to satisfy higher needs" reasons that the transformational leader, once s/he has constructed a judgment of the follower's motives, will attempt to utilize those perceived motives to induce desirable behaviors and attitudes. As should be understood from this, the degree to which a leader is a good judge is of theoretical importance to his or her ability to influence followers (Lord \& Maher, 1993; Shamir, House, \& Arthur, 1993). However, to the best of our knowledge, this proposition has not been empirically tested. Rather, it has been treated as an underlying, overlooked assumption of the leadership process. For instance, LMX theory proposes that the quality of relationships created and maintained with followers is critical to a leader's influence (Dulebohn et al., 2012; H. Wang et al., 2005). However, the development of those relationships is fundamentally dependent upon one's ability to accurately perceive the other (Asch, 1946; Nahrgang, Morgeson, \& Ilies, 2009). Therefore, without an accurate understanding of each individual follower, a leader's ability to provide individualized consideration, inspirational motivation, intellectual stimulation, and idealized influence is deeply compromised. For these simple yet impactful reasons, the tenability of this assumption should be tested empirically.

Following this line of reasoning, we refer to the last pages of Thoms' (2004) book, where the declaration is made that "leaders must learn to recognize the [personality and individual differences] among people and 
adjust their own behavior" (p. 144). This recommendation comes after the assertion that leaders rise into their position due in part to processing efficiency, which may be at the expense/risk of overgeneralization or stereotyping when interacting with followers. While this position is strong, it is not lost on deaf ears and is captured within the purview of this paper. Broadly speaking, we posit that the accuracy with which leaders are able to judge the VABEs of followers is an important moderator of LMX and transformational leadership. Providing support for this proposition, Galinsky, $\mathrm{Ku}$, and Wang (2005) recommended perspective-taking as a tactic to form and strengthen social bonds. This makes intuitive sense, as being seen accurately improves feelings of connectedness and, therefore, allows for stronger social relationships (Human, Sandstrom, Biesanz, \& Dunn, 2013). By virtue of increased LMX quality, the transforming leader can provide intellectual stimulation and individualize consideration to assign tasks (Bass \& Riggio, 2006; Northouse, 2010) that are considered self-expanding (Aron \& Aron, 2009; Aron et al., 2001), intrinsically motivating, and/or extrinsically motivating (Ryan \& Deci, 2000) to the follower, which will then facilitate greater performance (Gray et al., 2015). We developed an integrative path model of such processes, which is seen in Figure 4.

FIGURE 4

\section{AN INTEGRATIVE PATH MODEL CONCEPTUALIZED FROM THE DISCUSSION AND ARGUMENTS PRESENTED IN THIS PAPER. PATHS REPRESENT THOSE LINKS FOUND WITHIN THE EXISTING LITERATURE, AS WELL AS THOSE OF EMPIRICAL AND THEORETICAL INTEREST}

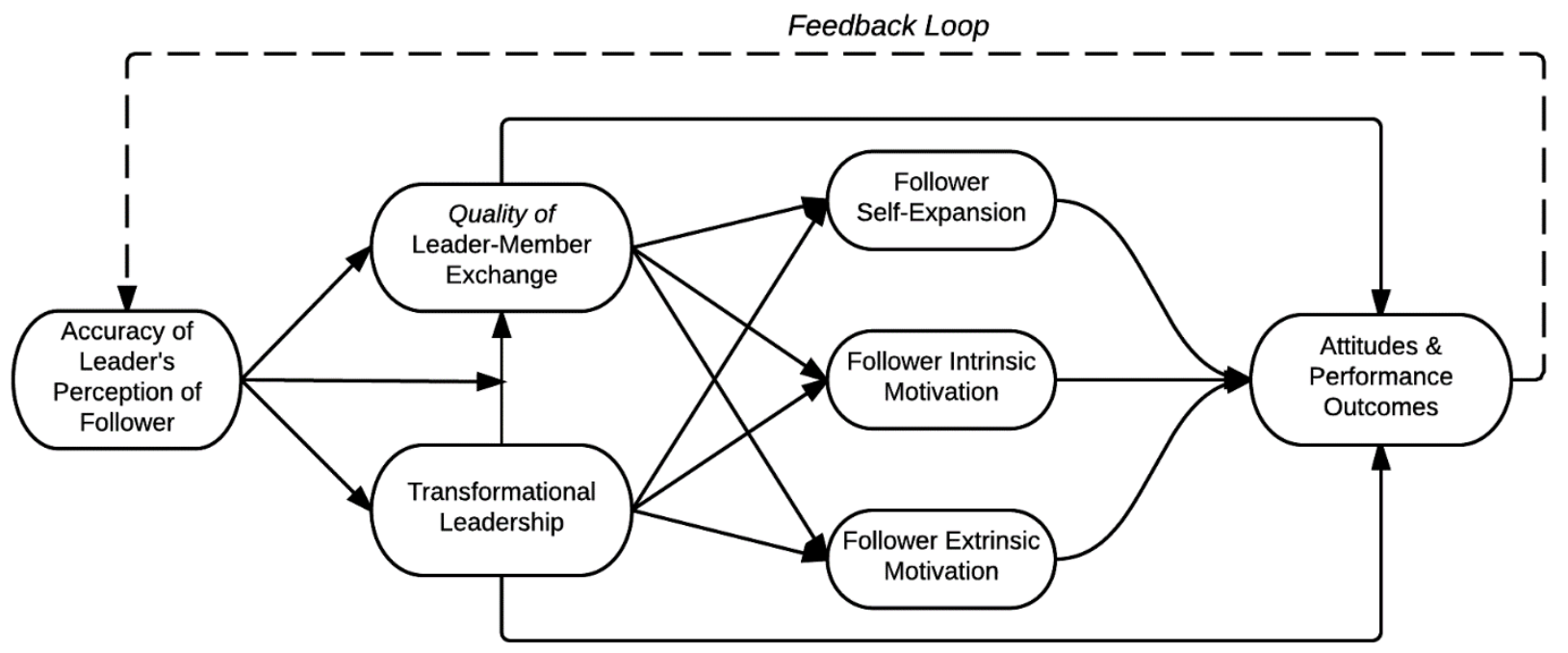

\section{An Integrative Perspective}

Culminating from this review is an integrative perspective which takes, what we believe is, a more holistic approach to leadership. It accounts for the linkages between follower personality, supervisor leadership style, and interpersonal processes that allow for the effective influence of attitudes and behaviors. While previous leadership and behavior path models have led to favorable outcomes (e.g., Aryee \& Chen, 2006; Gray et al., 2015; Harris et al., 2009; Podsakoff et al., 1990), we feel that this approach can be more effective in achieving organizational performance metrics (e.g., quality), not to mention meeting employee needs (e.g., autonomy support).

When a leader attempts to understand the whole follower, and does so with accuracy, the opportunities for influence are expanded. Specifically, through an understanding of followers' higher-order traits and motivational mechanisms, the leader can design work tasks, alter the operating environment, and determine appropriate levels of autonomy to increase performance and relevant attitudes (e.g., job satisfaction). An example of this is the leader more effectively aligning followers' needs with the organizational mission. 
Considering and embracing followers' talents, motives, and individual characteristics makes this possible without changing the scope of the work. Another example of its application is in terms of performance improvement efforts (e.g., interventions, job re-design, etc.). By more accurately understanding the follower, the leader can deploy more fitting or appropriate performance improvement solutions, such as team-based training for workgroups that have higher needs for relatedness, or individual one-on-one coaching for an introvert.

Furthermore, with an understanding of the VABEs operating at L3, transformational leadership will be more effective. Leaders will be primed to provide the necessary intellectual stimulation (providing challenging, but not threatening tasks), individual consideration, idealized influence, and inspirational motivation. Much of this may be accomplished through the reframing of the organizational mission, vision, and goals (Bass, 1985; Bass \& Riggio, 2006) to match, or at least be compatible, with followers semiconscious VABEs at L3 and conscious thoughts and attitudes at L2 (Clawson, 2002). Optimally, once the organizational mission, vision, and goals are embraced, followers' actions at L1 should be the desirable behaviors (Clawson, 2002; Ryan \& Deci, 2008; Schein, 2004).

Beyond the utility of this integrated model as an avenue for increasing scholarly understanding of the leadership process, it has applied pragmatic implications. Specifically, if leader's perceptual accuracy is empirically shown to reliably increase follower motivations and thus quality of performance outcomes then, at a leadership development level, industry needs to continue to explore means to efficiently improve leaders' personality judgment accuracy. For instance, encouraging leaders to get to know their followers well and seek to form accurate impressions seems like a viable option (Biesanz \& Human, 2010). Furthermore, it would be prudent to inspire such leaders to regularly take the perspective of and express empathy toward followers, as such actions can facilitate deeper understanding and, therefore, accuracy in perceiving others (Bernstein \& Davis, 1982; Colman et al., 2017). However, one might assert that such primes must be ongoing. To this criticism, we would argue that the initial boost in accuracy should induce desired follower outputs. From that behavior, the leader will adjust their impression to be more accurate, at which time the cycle would start over again (see the feedback loop in Figure 4).

Once this non-recursive path model is in action, the feedback loop corresponds to an iterative judgment process. Returning to the RAM, recall that targets must behave in a manner that is relevant to their characteristics and those behaviors must be available. The end of the model, where the feedback loop begins, constitutes the point where such cues are made available by the follower. At this point, the feedback loop serves as a transition where leaders detect relevant and available cues and integrate that new information into his/her construal of the follower. Such a revision to ones' perceptions is a critical part of early interpersonal relations (Asch, 1946; Nahrgang et al., 2009). Without refining their understanding of individual followers, leaders and managers will not alter their actions in a way that they believe will improve work attitudes and performance outcomes.

\section{Empirical Considerations and Conclusion}

Individually, each of the areas presented and integrated within this paper - behaviors and attitudes, personality, leadership, and interpersonal relations - have a vast research literature. However, the integration of these topics presented herein is a novel theoretical approach that is incremental in nature. While most pairings among these areas has been subject to some level of theoretical and/or empirical investigation, to our knowledge, research that incorporates all of these is absent. To this point, the integrative model presented leaves many research propositions ripe for empirical exploration.

Further research should begin with exploring the relationship between accuracy and each of the constructs, and then the mediating effects of accuracy among the various constructs. This is especially true as it relates to models that are relationally based, such as the LMX. On an intuitive level, it makes sense that accuracy is a foundational component of LMX, but as established already, there is a gap in the literature. Finally, in light of the body of literature that examines the relationships between follower self-expansion and follower motivation with both LMX and transformational leadership (e.g., Bass \& Riggio, 2006; Dansereau et al., 2013; Gray et al., 2015; McIntyre et al., 2014), there is a need to eventually test the entire 
path model. This would provide further evidence of the overarching role of accuracy in the leader-follower framework, as well as illuminate the impact of the feedback loop.

Ultimately, because a firm's workforce carries out the essential actions by acting as the mind (leadership), body (workforce), and soul (collective purpose) of the organization, it is essential to understand how individual differences (e.g., motivation, Big Five traits), the style of leadership, and the ability to accurately assess others attenuate key behaviors and attitudes. Overall, successful leadership is a highly dynamic and relational process that demands consideration of all of these variables, and, more importantly, the interactions among them. Thus, as argued herein, the ability to make, and properly utilize, accurate judgments of others is critical to the ability to meaningfully influence employees' behaviors and attitudes that coincide with the mission, vision, and performance goals of any firm.

\section{ENDNOTES}

1. Given the purpose of this paper, the review of the differences between Management and Leadership is pithy. However, for an in-depth review of the definitional, conceptual, functional, and behavioral distinctions see Toor and Ofori (2008).

2. We have taken the liberty of replacing the term leadership with supervision as neither the term management nor leadership capture this style.

3. A laissez-faire approach may be acceptable in situations where the outcome only matters to the individuals directly contributing to it (Bass \& Riggio, 2006). However, it could be argued that such a situation is not within the purview of leadership.

4. We have taken the liberty of replacing the term leadership with management to provide consistency with the Management vs. Leadership discussion above.

\section{REFERENCES}

Ajzen, I. (2001). Nature and operation of attitudes. Annual Review of Psychology, 52, 27-58. doi:10.1146/annurev.psych.52.1.27

Allik, J., de Vries, R.E., \& Realo, A. (2016). Why are moderators of self-other agreement difficult to establish? Journal of Research in Personality, 63, 72-83. doi:10.1016/j.jrp.2016.05.013

Aron, A., \& Aron, E. (2009). The self-expansion model. In H.T. Reis \& S. Sprecher (Eds.), Encyclopedia of human relationships. Thousand Oaks, CA: Sage.

Aron, A., Aron, E.N., \& Norman, C. (2001). Self-expansion model of motivation and congition in close relationships and beyond. In G.J.O. Fletcher \& M.S. Clark (Eds.), Blackwell handbook of social psychology: Interpersonal processes (pp. 478-501). Malden, MA: Blackwell Publishing.

Aron, A., Lewandowski, G.W., Mashek, D., \& Aron, E.N. (2013). The self-expansion model of motivation and cognition in close relationships. In J.A. Simpson \& L. Campbell (Eds.), The Oxford handbook or close relationships. New York: Oxford University Press.

Aryee, S., \& Chen, Z.X. (2006). Leader-member exchange in a Chinese context: Antecedents, the mediating role of psychological empowerment and outcomes. Journal of Business Research, 59, 793-801. doi:10.1016/j.jbusres.2005.03.003

Asch, S.E. (1946). Forming impressions of personality. The Journal of Abnormal and Social Psychology, 41, 258-290. doi:10.1037/h0055756

Avolio, B.J., Bass, B.M., \& Jung, D.I. (1999). Re-examining the components of transformational and transactional leadership using the Multifactor Leadership Questionnaire. Journal of Occupational and Organizational Psychology, 72, 441-462. doi:10.1348/096317999166789

Back, M.D., \& Nestler, S. (2016). Judging personality. In J.A. Hall, M. Schmid Mast, \& T.V. West (Eds.), The social psychology of perceiving others accurately (pp. 98-124). Cambridge, UK: Cambridge University Press.

Barling, J., Weber, T., \& Kelloway, E.K. (1996). Effects of transformational leadership training on attitudinal and financial outcomes: A field experiment. Journal of Applied Psychology, 81, 827832. doi:10.1037/0021-9010.81.6.827 
Barrick, M.R., \& Mount, M.K. (1991). The Big Five personality dimensions and job performance: A meta-analysis. Personnel Psychology, 44, 1-26.

Baruch-Feldman, C., Brondolo, E., Ben-Dayan, D., \& Schwartz, J.L.K. (2002). Sources of social support and burnout, job satisfaction, and productivity. Journal of Occupational Health Psychology, 7 , 84-93. doi:10.1037/1076-8998.7.1.84

Bass, B.M. (1985). Leadership and performance beyond expectations. New York, NY: The Free Press.

Bass, B.M., \& Avolio, B.J. (1993). Transformational leadership and organizational culture. Public Administration Quarterly, 17, 112-121.

Bass, B.M., \& Riggio, R.E. (2006). Transformational leadership (2nd ed.). New York, NY: Psychology Press.

Bernstein, W.M., \& Davis, M.H. (1982). Perspective-taking, self-consciousness, and accuracy of person perception. Basic and Applied Social Psychology, 3, 1-19.

Biesanz, J.C., \& Human, L.J. (2010). The cost of forming more accurate impressions: Accuracymotivated perceivers see the personality of others more distinctively but less normatively than perceivers without an explicit goal. Psychological Science, 21, 589-594. doi:10.1177/0956797610364121

Blau, P.M., \& Scott, W.R. (1962). Formal organizations: A comparative approach. Stanford, CA: Stanford University Press.

Boerner, S., Eisenbeiss, S.A., \& Griesser, D. (2007). Follower behavior and organizational performance: The impact of transformational leaders. Journal of Leadership and Organizational Studies, 13, $15-26$.

Bono, J.E., \& Judge, T.A. (2003). Self-concordance at work: Toward understanding the motivational effects of transformational leaders. Academy of Management Journal, 46, 554-571.

Burns, J.M. (1978). Leadership. New York, NY: Harper \& Row.

Carvone, D. (1997). Social-cognitive mechanisms and personality coherence: Self-knowledge, situational beliefs, and cross-situational coherence in perceived self-efficacy. Psychological Science, 8, 4350 .

Carvone, D., \& Shoda, Y. (1999). Beyond traits in the study of personality coherence. Current Directions in Psychological Science, 8, 27-32.

Cerasoli, C.P., Nicklin, J.M., \& Ford, M.T. (2014). Intrinsic motivation and extrinsic incentives jointly predict performance: A 40-year meta-analysis. Psychological Bulletin, 140, 980-1008. doi:10.1037/a0035661

Christiansen, N.D., Wolcott-Burnam, S., Janovics, J.E., Burns, G.N., \& Quirk, S.W. (2005). The good judge revisited: Individual differences in the accuracy of personality judgments. Human Performance, 18, 123-149. doi:10.1207/s15327043hup1802_2

Clawson, J.G. (2002). Level three leadership. Prentice Hall.

Cogliser, C.C., Schriesheim, C.A., Scandura, T.A., \& Gardner, W.L. (2009). Balance in leader and follower perceptions of leader-member exchange: Relationships with performance and work attitudes. Leadership Quarterly, 20, 452-465. doi:10.1016/j.leaqua.2009.03.010

Colman, D.E., Letzring, T.D., \& Biesanz, J.C. (2017). Seeing and feeling your way to accurate personality judgments: The moderating role of perceiver empathic tendencies. Social Psychological and Personality Science. doi:10.1177/1948550617691097

Colquitt, J.A., Scott, B.A., \& LePine, J.A. (2007). Trust, trustworthiness, and trust propensity: A metaanalytic test of their unique relationships with risk taking and job performance. Journal of Applied Psychology, 92, 909-927. doi:10.1037/0021-9010.92.4.909

Dansereau, F., Graen, G.B., \& Haga, W.J. (1975). A vertical dyad linkage approach to leadership within formal organizations. Organizational Behavior and Human Performance, 13, 46-78.

Dansereau, F., Seitz, S.R., Chiu, C., Shaughnessy, B., \& Yammarino, F.J. (2013). What makes leadership, leadership? Using self-expansion theory to integrate traditional and contemporary approaches. Leadership Quarterly, 24, 798-821. doi:10.1016/j.ladqua.2013.10.008 
Deci, E.L., \& Ryan, R.M. (2000). The "what" and "why" of goal pursuits: Human needs and the selfdetermination of behavior. Psychological Inquiry, 11, 227-268. doi:10.1207/S15327965pli1104_01

Deluga, R.J. (1992). The relationship of leader-member exchange with laissez-faire, transactional, and transformational leadership in naval environments. In K.E. Clark, M.B. Clark, \& D.P. Campbell (Eds.), Impact of leadership. Greensboro, NC: Center for Creative Leadership.

Dulebohn, J.H., Bommer, W.H., Liden, R.C., Brouer, R.L., \& Ferris, G.R. (2012). A meta-analysis of antecedents and consequences of leader-member exchange: Integrating the past with an eye toward the future. Journal of Management, 38, 1715-1759. doi:10.1177/0149206311415280

Festinger, L., \& Carlsmith, J.M. (1959). Cognitive consequences of forced compliance. Journal of Abnormal Psychology, 58, 203-210.

Funder, D.C. (1995). On the accuracy of personality judgment: A realistic approach. Psychological Review, 102, 652-670.

Funder, D.C. (2001). Personality. Annual Review of Psychology, 52, 197-221. doi:10.1146/annurev.psych.52.1.197

Funder, D.C. (2012). Accurate personality judgment. Current Directions in Psychological Science, 21, 177-182. doi:10.1177/0963721412445309

Gagné, M., \& Deci, E.L. (2005). Self-determination theory and work motivation. Journal of Organizational Behavior, 26, 331-362. doi:10.1002/job.322

Galinsky, A.D., Ku, G., \& Wang, C.S. (2005). Perspective-taking and self-other overlap: Fostering social bonds and facilitating social coordination. Group Processes \& Intergroup Relations, 8, 109-124. doi:10.1177/1368430205051060

Galinsky, A.D., Maddux, W.W., Gilin, D., \& White, J.B. (2008). Why it pays to get inside the head of your opponent: The differential effects of perspective taking and empathy in negotiations. Psychological Science, 19, 378-384.

Galinsky, A.D., Magee, J.C., Rus, D., Rothman, N.B., \& Todd, A.R. (2014). Acceleration with steering: The synergistic benefits of combining power and perspective-taking. Social Psychological and Personality Science, 5, 627-635. doi:10.1177/1948550613519685

Galinsky, A.D., \& Moskowitz, G.B. (2000). Perspective-taking: Decreasing stereotype expression, stereotype accessibility, and in-group favoritism. Journal of Personality and Social Psychology, 78, 708-724. doi:10.1037/0022-3514.78.4.708

George, L.G., Helson, R., \& John, O.P. (2011). The "CEO" of women's work lives: How Big Five Conscientiousness, Extraversion, and Openness predict 50 years of work experiences in a changing sociocultural context. Journal of Personality and Social Psychology, 101, 812-830. doi: $10.1037 / \mathrm{a} 0024290$

Glasman, L.R., \& Albarracin, D. (2006). Forming attitudes that predict future behavior: A meta-analysis of the attitude-behavior relation. Psychological Bulletin, 132, 778-822. doi:10.1037/00332909.132.5.778

Goldberg, L.R. (1993). The structure of phenotypic personality traits. American Psychologist, 48, $26-34$.

Graen, G.B., \& Uhl-Bien, M. (1991). The transformational of professionals into self-managing and partially self-designing contributors: Toward a theory of leadership-making. Journal of Management Systems, 3, 25-39.

Graen, G.B., \& Uhl-Bien, M. (1995). Relationship-based approach to leadership: Development of leadermember exchange (LMX) theory of leadership over 25 years: Applying a multi-level multidomain perspective. Leadership Quarterly, 6, 219-247.

Gray, C., McIntyre, K.P., Mattingly, B.A., \& Lewandowski, G.W. (2015). Follow the (self-expanding) leader: Using the self-expansion model to understand the impact of workplace leadership. Unpublished manuscript.

Griffin, R.W., \& Moorhead, G. (2010). Organizatinal Behavior: Managing people and organizations (9th ed.). Mason, $\mathrm{OH}$ : Cengage. 
Harris, K.J., Wheeler, A.R., \& Kacmar, K.M. (2009). Leader-member exchange and empowerment: Direct and interactive effects on job satisfaction, turnover intentions, and performance. Leadership Quarterly, 20, 371-382. doi:10.1016/j.leaqua.2009.03.006

Hay, A., \& Hodgkinson, M. (2006). Rethinking leadership: A way forward for teaching leadership? Leadership \& Organization Development Journal, 27, 144-158.

Human, L.J., Sandstrom, G.M., Biesanz, J.C., \& Dunn, E.W. (2013). Accurate first impressions leave a lasting impression: The long-term effects of distinctive self-other agreement on relationship development. Social Psychological and Personality Science, 4, 395-402. doi:10.1177/1948550612463735

Ilies, R., Nahrgang, J.D., \& Morgeson, F.P. (2007). Leader-member exchange and citizenship behaviors: A meta-analysis. Journal of Applied Psychology, 92, 269-277. doi:10.1037/0021-9010.92.1.269

Jahoda, M. (1981). Work, employment, and unemployment: Values, theories, and approaches in social research. American Psychologist, 36, 184-191.

Judge, T.A., \& Bono, J.E. (2000). Five-factor model of personality and transformational leadership. Journal of Applied Psychology, 85(5), 751-765.

Judge, T.A., Heller, D., \& Mount, M.K. (2002). Five-factor model of personality and job satisfaction: A meta-analysis. Journal of Applied Psychology, 87(3), 530-541.

Judge, T.A., Higgins, C.A., Thoresen, C.J., \& Barrick, M.R. (1999). The big five personality traits, general mental ability, and career success across the life span. Personnel Psychology, 52.

Judge, T.A., \& Ilies, R. (2002). Relationship of personality to performance motivation: A meta-analytic review. Journal of Applied Psychology, 87, 797-807. doi:10.1037/0021-9010.87.4.797

Judge, T.A., Klinger, R.L., Simon, L.S., \& Yang, I.W.F. (2008). The contributions of personality to organizational behavior and psychology: Findings, criticisms, and future research directions. Social and Personality Compass, 2(5), 1982-2000. doi:10.1111/j.1751-9004.2008.00136.x

Judge, T.A., \& Piccolo, R.F. (2004). Transformational and transactional leadership: A meta-analytic test of their relative validity. Journal of Applied Psychology, 89, 755-768. doi:10.1037/00219010.89.5.755

Judge, T.A., Rodell, J.B., Klinger, R.L., Simon, L.S., \& Crawford, E.R. (2013). Hierarchical representations of the five-factor model of personality in predicting job performance: Integrating three organizing frameworks with two theoretical perspectives. Journal of Applied Psychology, 98(6), 875-925. doi:10.1037/a0033901

Judge, T.A., Thoresen, C.J., Bono, J.E., \& Patton, G.K. (2001). The job satisfaction-job performance relationship: A qualitative and quantitative review. Psychological Bulletin, 127, 376-407.

Jung, D.I., \& Avolio, B.J. (2000). Opening the black box: An experimental investigation of the mediating effects of trust and value congruence on transformational and transactional leadership. Journal of Organizational Behavior, 21, 949-964.

Kerr, S. (1995). On the folly of rewarding A, while hoping for B. The Academy of Management Executive, 9, 7-14.

Kotter, J.P. (2001). What leaders really do. Harvard Business Review, 79, 85-94.

Koys, D.J. (2001). The effects of employee satisfaction, organizational citizenship behavior, and turnover on organizational effectiveness: A unit-level, longitudinal study. Personnel Psychology, 54, 101114. doi:10.1111/j.1744-6570.2001.tb00087.x

Krishnan, V.R. (2005). Leader-member exchange, transformational leadership, and value system. Electronic Journal of Business Ethics and Organizational Studies, 10, 14-21.

Leary, M.R. (2007). Motivational and emotional aspects of the self. Annual Review of Psychology, 58, 317-344. doi:10.1146/annurev.psych.58.110405.085658

Letzring, T.D. (2008). The good judge of personality: Characteristics, behaviors, and observer accuracy. Journal of Research in Personality, 42, 914-932. doi:10.1016/j.jrp.2007.12.003

Locke, E.A., \& Latham, G.P. (2002). Building a practically useful theory of goal setting and task motivation: A 35-year odyssey. American Psychologist, 57, 705-717. doi:10.1037/0003066x.57.9.705 
Locke, E.A., \& Latham, G.P. (2006). New directions in goal-setting theory. Current Directions in Psychological Science, 15, 265-268.

Lord, R.G., Brown, D.J., \& Freiberg, S.J. (1999). Understanding the dynamics of leadership: The role of follower self-concepts in the leader/follower relationship. Organizational Behavior and Human Decision Processes, 78, 167-203. doi:10.1006/obhd.1999.2832

Lord, R.G., \& Maher, K.J. (1993). Leadership and information processing: Linking perceptions and performance. New York, NY: Routledge.

Mattingly, B.A., McIntyre, K.P., \& Lewandowski, G.W. (2012). Approach motivation and the expansion of self in close relationships. Personal Relationships, 19, 113-127. doi:10.1111/j.14756811.2010.01343.x

McIntyre, K.P., Mattingly, B.A., Lewandowski, G.W., \& Simpson, A. (2014). Workplace self-expansion: Implications for job satisfaction, commitment, self-concept clarity, and self-esteem among the employed and unemployed. Basic and Applied Social Psychology, 36, 59-69. doi:10.1080/01973533.2013.856788

Nahrgang, J.D., Morgeson, F.P., \& Ilies, R. (2009). The development of leader-member exchanges: Exploring how personality and performance influence leader and member relationships over time. Organizational Behavior and Human Decision Processes, 108, 256-266. doi:10.1016/j.obhdp.2008.09.002

Northouse, P.G. (2010). Leadership: Theory and practice (5th ed.). Thousand Oaks, CA: Sage.

Organ, D.W. (1997). Organizational citizenship behavior: It's construct clean-up time. Human Performance, 10, 85-97. doi:10.1207/s15327043hup1002_2

Ouchi, W.G. (1980). Markets, bureaucracies, and clans. Administrative Science Quarterly, 25, 129-141.

Patall, E.A., Cooper, H., \& Robinson, J.C. (2008). The effects of choice on intrinsic motivation and related outcomes: A meta-analysis of research findings. Psychological Bulletin, 134, 270-300. doi:10.1037/0033-2909.134.2.270

Pinder, C.C. (2008). Work motivation in organizational behavior (2nd ed.). New York, NY: Psychology Press.

Podsakoff, P.M., MacKenzie, S.B., Moorman, R.H., \& Fetter, R. (1990). Transformational leader behaviors and their effects on followers' trust in leader, satisfaction, and organizational citizenship behaviors. Leadership Quarterly, 1, 107-142.

Ryan, R.M., \& Deci, E.L. (2000). Intrinsic and extrinsic motivations: Classic definitions and new directions. Contemporary Educational Psychology, 25, 54-67. doi:10.1006/ceps.1999.1020

Ryan, R.M., \& Deci, E.L. (2008). Self-determination theory and the role of basic psychological needs in personality and the organization of behavior. In O.P. John, R.W. Robins, \& L.A. Pervin (Eds.), Handbook of Personality: Theory and Research (3rd ed., pp. 654-678). New York, NY: The Guilford Press.

Ryan, R.M., \& Deci, E.L. (2017). Self-determination theory: Basic psychological needs in motivation development and wellness. New York: Guilford Publishing.

Schein, E.H. (2004). Organizational culture and leadership (3rd ed.). San Francisco, CA: Jossey-Bass.

Shamir, B., House, R.J., \& Arthur, M.B. (1993). The motivational effects of charismatic leadership: A self-concept based theory. Organization Science, 4, 577-594. doi:10.1287/orsc.4.4.577

Sheldon, K.M., \& Kasser, T. (1995). Coherence and congruence: Two aspects of personality integration. Journal of Personality and Social Psychology, 68, 531-543.

Shore, J.M., \& Martin, H.J. (1989). Job satisfaction and organizational commitment in relation to work performance and turnover intentions Human Relations, 42, 625-638.

Smith, C.A., Organ, D.W., \& Near, J.P. (1983). Organizational citizenship behavior: Its nature and antecedents. Journal of Applied Psychology, 68, 653-663.

Srivastava, S. (2016). Measuring the big five personality factors. Retrieved from http://psdlab.uoregon.edu/bigfive.html

Stajkovic, A.D., \& Luthans, F. (1998). Self-efficacy and work-related performance: A meta-analysis. Psychological Bulletin, 124, 240-261. doi:Doi 10.1037/0033-2909.124.2.240 
Steers, R.M., Mowday, R.T., \& Shapiro, D.L. (2004). The future of work motivation theory. Academy of Management Review, 29, 379-387.

Taft, R. (1955). The ability to judge people. Psychological Bulletin, 52, 1-23.

Thoms, P. (2004). Driven by time: Time orientation and leadership. Westport, CT: Praeger.

Toor, S., \& Ofori, G. (2008). Leadership versus management: How they are different and why. Leadership and Management in Engineering, 8, 61-71.

Van Dyne, L., Graham, J.W., \& Dienesch, R.M. (1994). Organizational citizenship behavior: Construct redefinition, measurement, and validation. Academy of Management, 37, 765-802.

Wang, C.S., Ku, G., Tai, K., \& Galinsky, A.D. (2014). Stupid doctors and smart construction workers: Perspective-taking reduces stereotyping of both negative and positive targets. Social Psychological and Personality Science, 5, 430-436. doi:10.1177/1948550613504968

Wang, C.S., Tai, K., Ku, G., \& Galinsky, A.D. (2014). Perspective-taking increases willingness to engage in intergroup contact. PLOS ONE, 9, 1-8. doi:10.1371/journal.pone.0085681

Wang, G., Oh, I.S., Courtright, S.H., \& Colbert, A.E. (2011). Transformational leadership and performance across criteria and levels: A meta-analytic review of 25 years of research. Group \& Organization Management, 36, 223-270. doi:10.1177/1059601111401017

Wang, H., Law, K.S., Hackett, R.D., Wang, D., \& Chen, Z.X. (2005). Leader-member exchange as a mediator of the relationship between transformational leadership and followers' performance and organizational citizenship behavior. Academy of Management Journal, 48(3), 420-432.

Zaleznik, A. (1977). Managers and leaders: Are they different? Harvard Business Review, 55, 67-78.

Zuckerman, M., Porac, J., Lathin, D., Smith, R., \& Deci, E.L. (1978). On the importance of selfdetermination for intrensically-motivated behavior. Personality and Social Psychology Bulletin, $4,443-446$. 